\section{Assessment of Faecal Bacteria Contamination in Selected Coastal Waters of Tanzania}

\author{
Samson Lazaro’s Mwakalobo \\ University of Dar Es Salaam, P. O. Box 35048, Dar Es Salaam. Tanzania \\ Tel: 255-756-440-173Ｅ-mail: mwakalobo@yahoo.com
}

Dr. Lucy Namkinga (Corresponding author)

Department of Molecular Biology and Biotechnology, University of Dar Es Salaam

P. O. Box 35179. Dar Es Salaam. Tanzania

Tel: 255-784-772-552Ｅ-mail: odulajalucy@yahoo.com

Prof. Thomas Jacob Lyimo

Department of Molecular Biology and Biotechnology, University of Dar Es Salaam

P. O. Box 35179. Dar Es Salaam. Tanzania

Tel: 255-754-375-924Ｅ-mail: tjlyimo@udsm.ac.tz

Dr. Charles Lugomela

Department of Aquatic Sciences and Fisheries, University of Dar Es Salaam

P.O. Box 35064 Dar Es Salaam, Tanzania

Tel: 255-784-230-023Ｅ-mail: lugomela@udsm.ac.tz

Received: December 17, 2012 Accepted: January 4, 2013

doi:10.5296/jbls.v4i2.3414 URL: http://dx.doi.org/10.5296/jbls.v4i2.3414

\begin{abstract}
Coastal communities of Tanzania use natural water systems such as rivers, estuaries and
\end{abstract}


marine for various activities like drinking, fishing, washing and bathing. However, there is scanty information on the safety for these water bodies for the various uses. In this study faecal indicator bacteria were assessed in three sites along the coast of Tanzania (i.e. Pangani Estuary in Tanga Region, Ruvu Estuary in Pwani Region and Mzinga Creek in Dar Es Salaam Region). At each site, three sampling stations covering fresh, brackish and marine waters were selected for monthly sampling between July 2009 and June 2010. Faecal bacterial indicators were generally higher in Mzinga Creek compared to the rest of the study sites with significant differences between Mzinga Creek and Pangani Estuary for total coliforms (TC) and faecal coliforms (FC) $(\mathrm{P}<0.05)$. All faecal indicator bacteria were significantly higher in fresh waters compared to brackish and marine waters $(\mathrm{P}=0.0001)$, for $\mathrm{TC}$ and $\mathrm{FC}$ and $\mathrm{P}=0.001$ for Enterococcus (ENT). The faecal indicator bacteria correlated positive to each other and negatively to some environmental parameters namely $\mathrm{pH}$ and Salinity. Results suggest allochthonous sources of contamination and the influence of environmental factors. Generally the faecal bacterial indicators in the studied waters along the coast of Tanzania were within the acceptable standards according to WHO and USEPA indicating low risks situation for recreational purposes. However, these levels of faecal bacteria does not warrant the use in the studied estuaries for shellfish harvesting and the fresh water is not suitable for direct drinking. Further studies and monitoring programs are recommended to substantiate the current results.

Keywords: Faecal bacteria, Coliforms, Coastal aquatic environment

\section{Introduction}

In many towns around the world, especially those in densely populated rural or urban areas the microbiological quality of waters is frequently threatened by pollution with untreated domestic wastewater. The risk of exposure to pathogens in drinking or recreational waters has been well described in the literature (WHO, 1998; 1999). Water borne diarrheal diseases, including salmonellosis, amoebiasis, shigellosis, cholera, or giardiasis are widespread in areas with contaminated water (Thompson and Khan, 2003; WHO and UNICEF, 2004; Grabow, 1996). In many developing countries, diarrheal diseases remain a major killer in children. Estimates by WHO and UNICEF (2004) indicates that $80 \%$ of all illnesses in developing countries is related to water and sanitation; and that $15 \%$ of all child deaths under the age of 5 years in developing countries are caused by diarrheal diseases" (WHO and UNICEF 2004; Thompson and Khan 2003). In developed countries, protection of water sources and treatment of water are done effectively in such a way that, diarrheal diseases and their incidences have been reduced greatly compared to underdeveloped countries. Many towns and villages in developing countries like in sub-Saharan Africa, do not have access to hygienic toilets and large amounts of faecal waste are discharged to the environment without adequate treatment. Outbreaks have been associated with swimming in crowded lakes (Ackman et al., 1997), contaminated drinking water (Olsen et al., 2002) as well as surface water (Effler et al., 2001).

Detection of pathogens in water samples is very difficult, and the use of indicator organisms to signal the potential presence of organisms that cause gastrointestinal disease concept has been used successfully for a long time. The faecal indicator bacteria such as Total coliform (TC), 
Faecal coliform (FC), E. coli and enterococci (ENT) or faecal streptococci are most commonly used today (USEPA, 1986; 1999; Griesel and Jagals, 2002; Hysko et al., 2010). Faecal indicator bacteria remains the major and most reliable tool in the assessment of the health risks posed by pathogens in water (Byamukama et al., 2000) as most faecal coliform bacteria do not cause diseases. However, a measure of their concentration provides an indication of the degree of faecal contamination and therefore, enlighten on the possibility of being exposed to disease-carrying organisms, which may be present in water. International standards (e.g. UNEP/WHO, EC, USEPA) have been set to regulate the levels of these faecal indicator bacteria as common indices of the suitability of waters (USEPA, 1999; WHO, 1999; 2003). The recommended limits for water to be used for recreation and related purposes, in many standards, are $<000 \mathrm{CFU} / 100 \mathrm{ml}$ for TC and >100 for FC and ENT (WHO 1999). However, among the three indicators, used in this study, ENT has been recommended as the most suitable indicator for fresh and marine water (WHO 1999). Using ENT as standard, water may be classified, with $95^{\text {th }}$ percentile, as (A) excellent, when values are below $10 \mathrm{CFU} / 100 \mathrm{ml}$; (B) good, when values are between 11 and $50 \mathrm{CFU} / 100 \mathrm{ml}$; (C) fair, between 51 and 200 CFU/100 $\mathrm{ml}$; (D) poor, between 201 and $1000 \mathrm{CFU} / 100 \mathrm{ml}$; and (E) very poor, when values above 1000 CFU/100 $\mathrm{ml}$ are obtained (WHO, 1999). when the water is classified as generally 'poor', various management measures must be taken to minimise health risks.

In Tanzania, water pollution is cited as one of the major causes of water-borne diseases that kill both children and adults. Cholera outbreaks are frequent and cause significant mortalities (Penrose et al., 2010, http://www.infoforhealth.org,). Indeed, the periodic outbreaks of cholera, diarrhea and typhoid diseases are mainly caused by using unsafe water (Lyimo et al., 2007 and the references therein). Several studies in coastal regions of Tanzania have associated water pollution with occurrence of various gastrointestinal diseases. For example Van Bruggen (1990), Mohammed (2002a \& b) and Mmochi and Francis (1999) reported high levels of coliforms and nutrients in the coastal waters of Zanzibar, Tanzania. Rubindamayugi (1996) made an attempt to assess the sanitary quality of River Msimbazi and Coastal waters in Dar es Salaam and came up with suggestions on restricting some of the areas for swimming, and shellfish fishery as faecal contamination counts in those areas was high. Likewise, Abbu and Lyimo (2007) found out that faecal bacteria contamination was significantly higher at Mtoni Kijichi, station close to city center than Rasi Dege site which is away from Dar es Salaam city center. All these studies were concentrated around Dar es Salaam and Zanzibar cities but there is scanty information on feacal bacterial contamination in other coastal areas. Thus, the current study expanded to other areas with the aim of making comparison and establishing baseline information to those areas.

\section{Methods}

\subsection{Study Sites and Samplings}

The current study was conducted in three sites along the coastal regions of Tanzania. These were Pangani Estuary in Tanga Region, Ruvu Estuary in Pwani Region and Mzinga Creek in Dar Es Salaam Region (Figure 1). In each site, there were three sampling stations established along a salinity gradient, i.e. fresh water (below 5\%o), brackish water (between 5 and 30\%o) and 


\section{Macrothink}

marine water (above 30\%) with an exception of Mzinga Creek in which there were only two established stations (brackish and marine). Sampling was conducted during spring high tides on monthly bases from July 2009 to June 2010.

Samples were collected using $500 \mathrm{ml}$ sterile bottles tightened on a graduated yard stick so as to sample at about $30 \mathrm{~cm}$ depth. Collected samples were immediately transferred to a cool box containing ice parks until the time of filtration, which never exceed 6 hours after collection (APHA, 2005). Environmental parameters (water temperature, salinity and $\mathrm{pH}$ ), were measured in situ at each station using a multi-parameter water quality checker (HoribaU-10, Japan). Rainfall values were obtained from Tanzania Meteorological Agency in Dar Es Salaam.
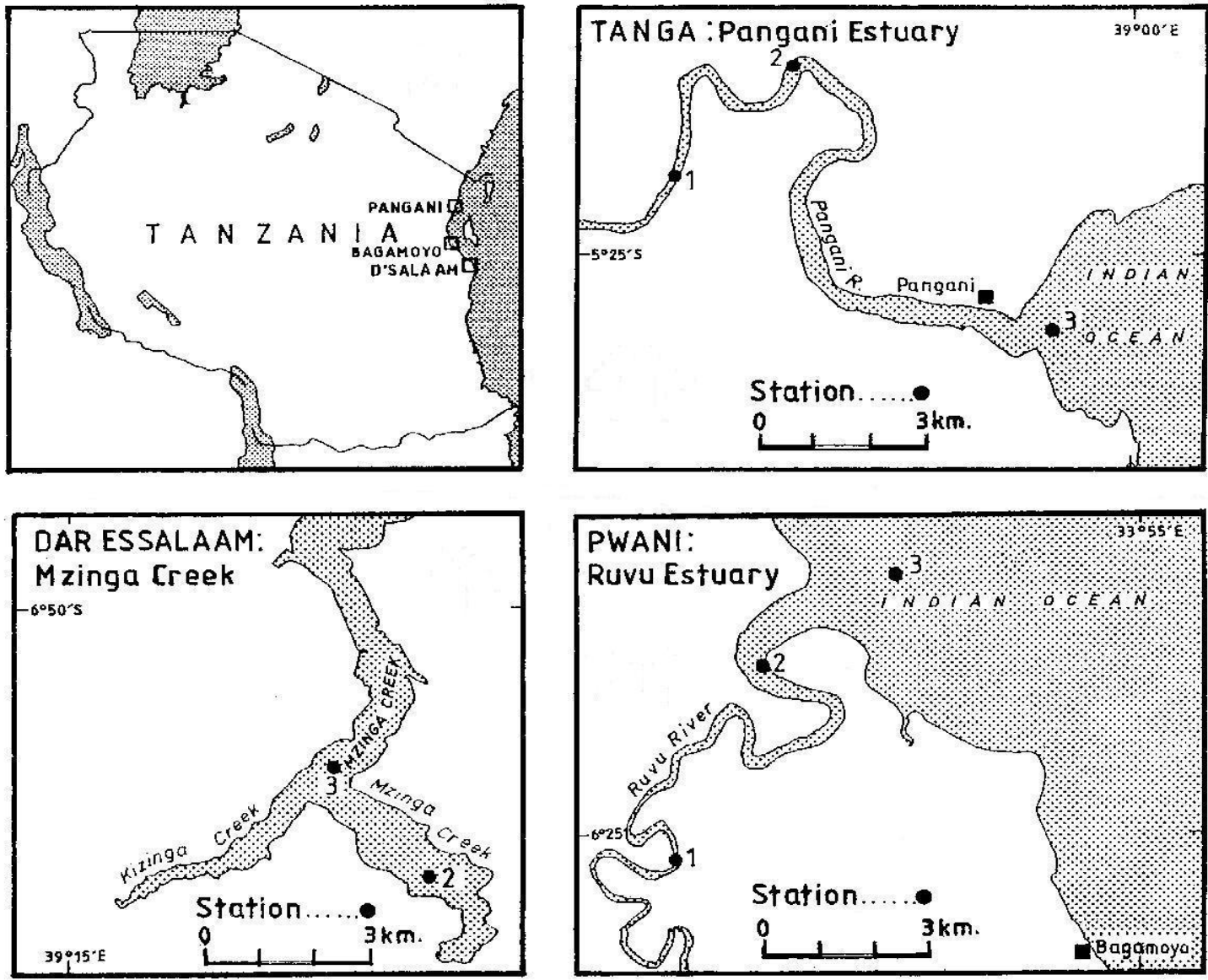

Figure 1. The map of Tanzania showing study sites (Pangani Estuary; Mzinga Creek and Ruvu Estuary) and sampling stations at each site.

\subsection{Microbiological Analysis}

Faecal bacteria were analysed using membrane techniques as described in American Health Public Association (APHA, 2005), whereby $100 \mathrm{ml}$ of undiluted and diluted (1 - 10 times) water sample were filtered through $0.45 \mu \mathrm{m}$ pore size membrane filters. The filters were transferred to two selective media i.e. Faecal Coliform Agar Base for coliforms and Slanetz Bratney Agar for enterococci (Conda Labs, Spain). Plates for Faecal coliform (FC) bacteria 
and for enterococci were incubated at $44.5 \pm 0.5 \mathrm{C}^{\circ}$ for $24 \mathrm{hrs}$. FC colonies appeared blue while enterococci colonies were reddish to brown. Plates for total coliform (TC) bacteria were incubated at $37 \pm 0.5 \mathrm{C}^{\circ}$ for 24 hours, where all brown to reddish colonies were counted as TC colonies.

\subsection{Statistical Analysis of Data}

The data collected were statistically analyzed as described by Zar (1999). Data were tested using a parametric two-way analysis of variance with its post hoc, Tukey-Kramer Multiple Comparison test. Where the assumptions for parametric tests were not met, data were analysed using a non-parametric Kruskal-Wallis (KW) test followed by the Dunn's Multiple Comparison Test. Also, Mann-Whitney U test was used to test the difference between values obtained in two sites. The statistical analysis were performed using GraphPad Instant tm 1990-1993 software. In all cases, significance was determined at the 95\% confidence level.

\section{Results}

\subsection{Faecal Bacterial Indicator Counts}

\subsubsection{General Faecal Indicator Bacteria Counts}

Among the three types of faecal indicator bacteria studied, the numbers of Total Coliform (TC) were significantly $(\mathrm{KW}=29 ; \mathrm{P}=0.0001)$ higher than Faecal Coliform (FC) and Enterococcus (ENT) with a mean value of $86.0 \pm 68.3,56.5 \pm 48.6$ and $39 \pm 32.2 \mathrm{CFU} / 100 \mathrm{ml}$, respectively. Dunn's multiple comparison test showed significant differences to be between TC and ENT $(\mathrm{P}<0.001)$ and between TC and FC $(\mathrm{P}<0.01)$ but not between FC and ENT $(\mathrm{P}>$ 0.05). In general freshwater (stations 1) had higher number of faecal indicator bacteria compared to brackish (station 2) and marine water (stations 3) $(\mathrm{KW}=86.2 ; \mathrm{P}=0.0001)$ with Dunn's multiple comparison test showing significant differences to be between freshwater and brackish water stations $(\mathrm{P}<0.05)$, and between freshwater and marine water $(\mathrm{P}<0.001)$ as well as between brackish and marine water $(\mathrm{P}<0.001)$. In addition, faecal bacterial indicators showed significant differences $(\mathrm{KW}=31.553$; $\mathrm{P}<0.0001)$ among sites with Dunns Multiple comparison test showing the significant differences to be between Pangani Estuary and Mzinga Creek $(\mathrm{P}<0.01)$ and Ruvu Estuary and Mzinga Creek $(\mathrm{P}<0.05)$ but not between Pangani and Ruvu Estuaries ( $\mathrm{P}>0.05)$.

\subsubsection{Total Coliform Counts}

Total Coliform counts ranged from zero $(0 \mathrm{CFU} / 100 \mathrm{ml})$ in various samples obtained from marine waters at Pangani and Ruvu Estuaries to a maximum of $336 \mathrm{CFU} / 100 \mathrm{ml}$ in brackish water station at Mzinga Creek site recorded in May 2010 (Figure 2). The counts for TC were not significantly different among sites $(\mathrm{KW}=5.7 ; \mathrm{P}>0.05)$. In Pangani Estuary, the number of TC averaged $63.8 \pm 37.9 \mathrm{CFU} / 100 \mathrm{ml}(\mathrm{n}=36)$ and was significantly different among sampling stations $(\mathrm{F}=25.02 ; \mathrm{P}<0.0001)$ with Tukey-Kramer Multiple Comparison Test showing significant differences to be between each station pair $(\mathrm{P}<0.001)$.

In Ruvu Estuary, the mean TC number was 87.2 $\pm 70 \mathrm{CFU} / 100 \mathrm{ml}(\mathrm{n}=36)$ and was significantly different among stations $(\mathrm{KW}=20.1 ; \mathrm{P}<0.0001)$ with Dunns Multiple 


\section{Macrothink}

comparison test showing the significant differences to be between freshwater ad marine station as well as between brackish water and marine station $(\mathrm{P}<0.001)$, but not between freshwater and brackish water stations $(\mathrm{P}>0.05)$. At Mzinga Creek, the mean TC number was $117.7 \pm$ 88.2 CFU/100 $\mathrm{ml}(\mathrm{n}=24)$. However, there was no significant difference in TC between the two sampling stations at this site $(\mathrm{U}=45.5 ; \mathrm{P}=0.1)$.
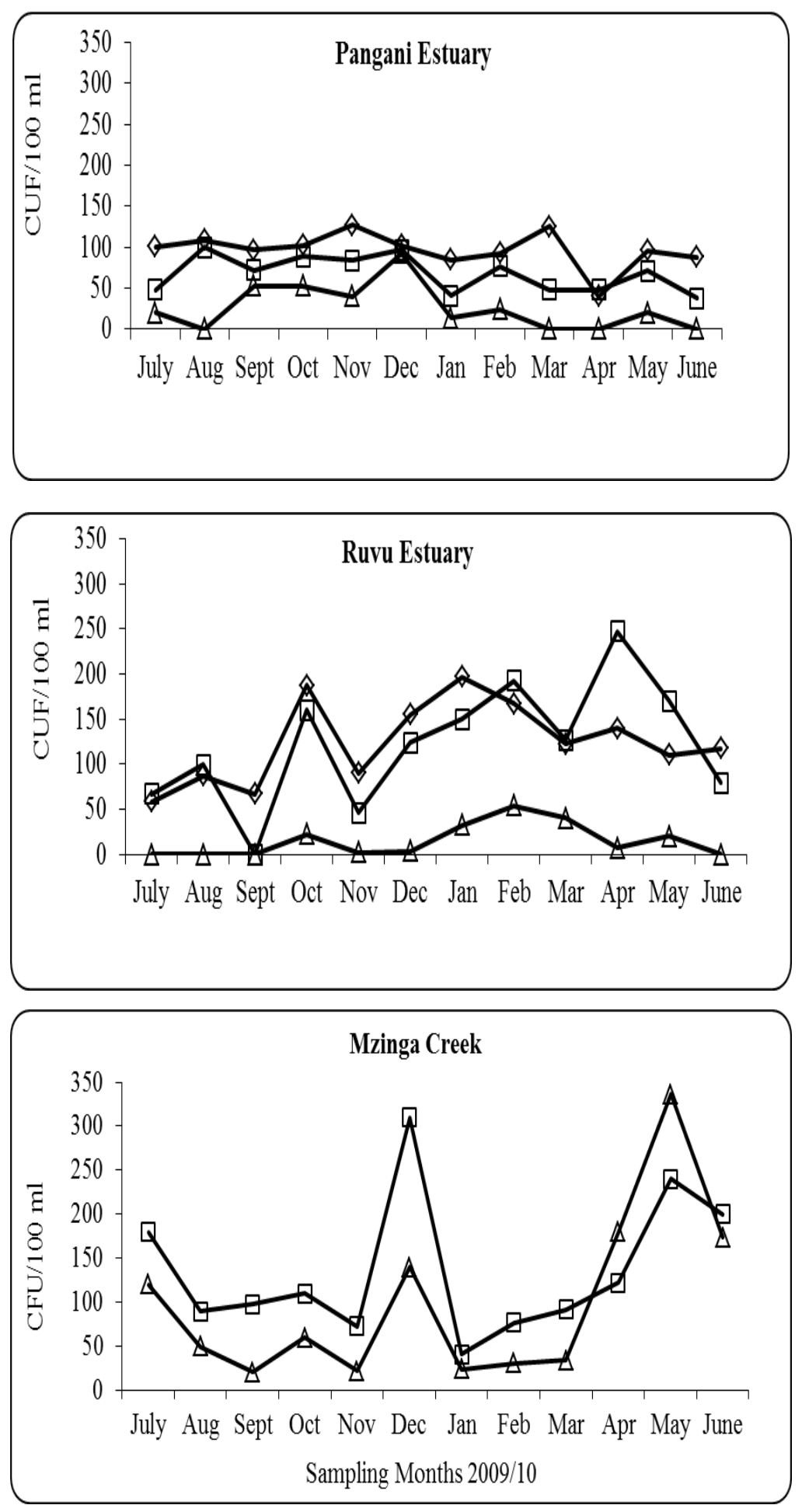

Figure 2. Seasonal variation in TC counts in the study sites $(\diamond=$ Station $1, \square=$ Station 2 and $\Delta=$ 
Station 3)

\subsubsection{Faecal Coliform Counts}

The results on seasonal variations of FC counts at various sampling sites and stations are shown in Figure 3. The FC counts ranged from $0 \mathrm{CFU} / 100 \mathrm{ml}$ as recorded in stations 3 of Pangani and Ruvu Estuaries to a maximum number of $200 \mathrm{CFU} / 100 \mathrm{ml}$ at station 2 in Mzinga Creek in December 2009. The counts for FC were significantly different among sites (KW = 7.3; $\mathrm{P}=0.03$ ) with post - hoc result showing the differences to be between Pangani Estuary and Mzinga Creek $(\mathrm{P}<0.05)$ but not between Pangani and Ruvu Estuaries as well as between Ruvu Estuary and Mzinga Creek (P>0.05).

In Pangani Estuary, FC counts at various sampling stations averaged $40.4 \pm 17.1 \mathrm{CFU} / 100 \mathrm{ml}$ and were significantly different among stations $(\mathrm{KW}=26.37 ; \mathrm{P}=0.0001)$ with post - hoc results showing the differences to be between freshwater and marine water stations $(\mathrm{P}<0.001)$ as well as between brackish water and marine water stations $(\mathrm{P}<0.01)$ but not between freshwater and brackish water stations $(\mathrm{P}>0.05)$.

In Ruvu Estuary, FC counts averaged 60.5 $\pm 35.9 \mathrm{CFU} / 100 \mathrm{ml}$ and were significantly different among stations $(\mathrm{KW}=21.40 ; \mathrm{P}=0.0001)$ with post - hoc result showing the differences to be between freshwater and marine water stations as well as between brackish and marine water stations $(\mathrm{P}<0.001)$. There were no significant differences between freshwater and brackish water stations $(\mathrm{P}>0.05)$. At Mzinga creek, the FC counts averaged 74.6 $\pm 41.7 \mathrm{CFU} / 100 \mathrm{ml}$. However, there was no significant difference between brackish and marine water stations $(\mathrm{P}>$ $0.05)$.

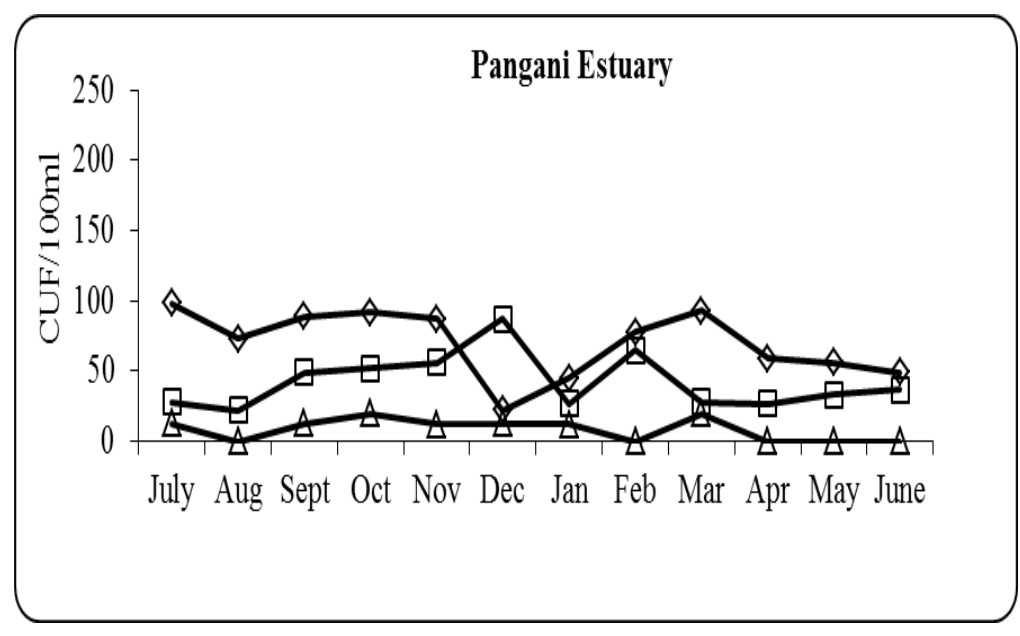



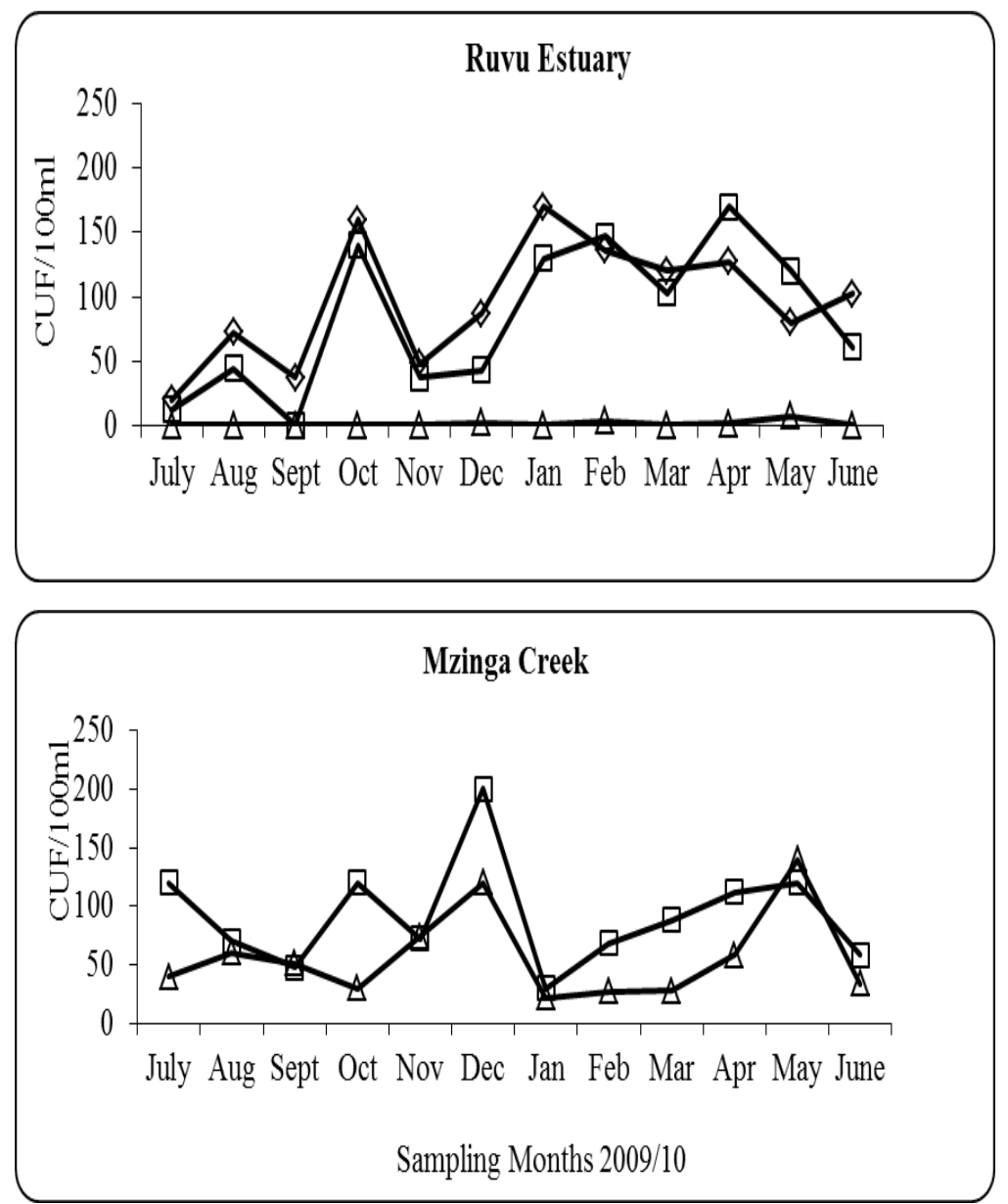

Figure 3. Seasonal variation in FC counts in the study sites $(\diamond=$ Station $1 ; \square=$ Station 2 and $\Delta=$ Station 3)

\subsubsection{Enterococcus Counts}

The results on seasonal variations of Enterococcus counts (CFU/100 ml) at various sampling sites and stations are shown in Figure 4. The ENT counts ranged from 0 CFU/100 $\mathrm{ml}$ in the marine water stations at Pangani and Ruvu Estuary during several sampling occasions to a maximum of $152 \mathrm{CFU} / 100 \mathrm{ml}$ in marine water station in Ruvu Estuary. However the numbers of ENT were not significantly different among sites $(\mathrm{KW}=4.393 ; \mathrm{P}=0.1)$.

In the Pangani Estuary, the numbers of ENT indicator bacteria averaged 37.5 $\pm 21.2 \mathrm{CFU} / 100$ $\mathrm{ml}$. The average numbers in different stations were $62.6 \pm 24.4,39.5 \pm 28.7$ and $10.4 \pm 10.6$ $\mathrm{CFU} / 100 \mathrm{ml}$ for fresh, brackish and marine water stations, respectively. ENT numbers differed significantly among stations $(\mathrm{KW}=20.2 ; \mathrm{P}=0.0001)$ with Dunns Multiple comparison test showing the significant differences to be between freshwater and marine water stations $(\mathrm{P}<$ $0.001)$ as well as between brackish water and marine water stations $(\mathrm{P}<0.01)$ but not between freshwater and brackish water stations $(\mathrm{P}>0.05)$.

In the Ruvu Estuary, the number of ENT counts averaged $35.6 \pm 26.5 \mathrm{CFU} / 100 \mathrm{ml}$. The average counts at different stations were $68.4 \pm 21,28 \pm 45$ and $10.3 \pm 13.5 \mathrm{CFU} / 100 \mathrm{ml}$ at fresh, brackish and marine stations, respectively. Statistically, the numbers differed 


\section{Ml Macrothink}

significantly among stations $(\mathrm{KW}=17.3 ; \mathrm{P}<0.0002)$ with Dunns Multiple comparison test showing the significant differences to be between freshwater and marine water stations $(\mathrm{P}<$ $0.01)$ as well as between freshwater and brackish water stations $(\mathrm{P}<0.001)$ but not between brackish and marine water stations $(\mathrm{P}>0.05)$.

In Mzinga Creek, the average number of ENT was $46.3 \pm 22.7 \mathrm{CFU} / 100 \mathrm{ml}$. The average counts at brackish and marine water stations were $53.7 \pm 24.1$ and $38.8 \pm 21.2 \mathrm{CFU} / 100 \mathrm{ml}$, respectively. However there was no significant difference between the two stations $(\mathrm{P}>0.05)$.
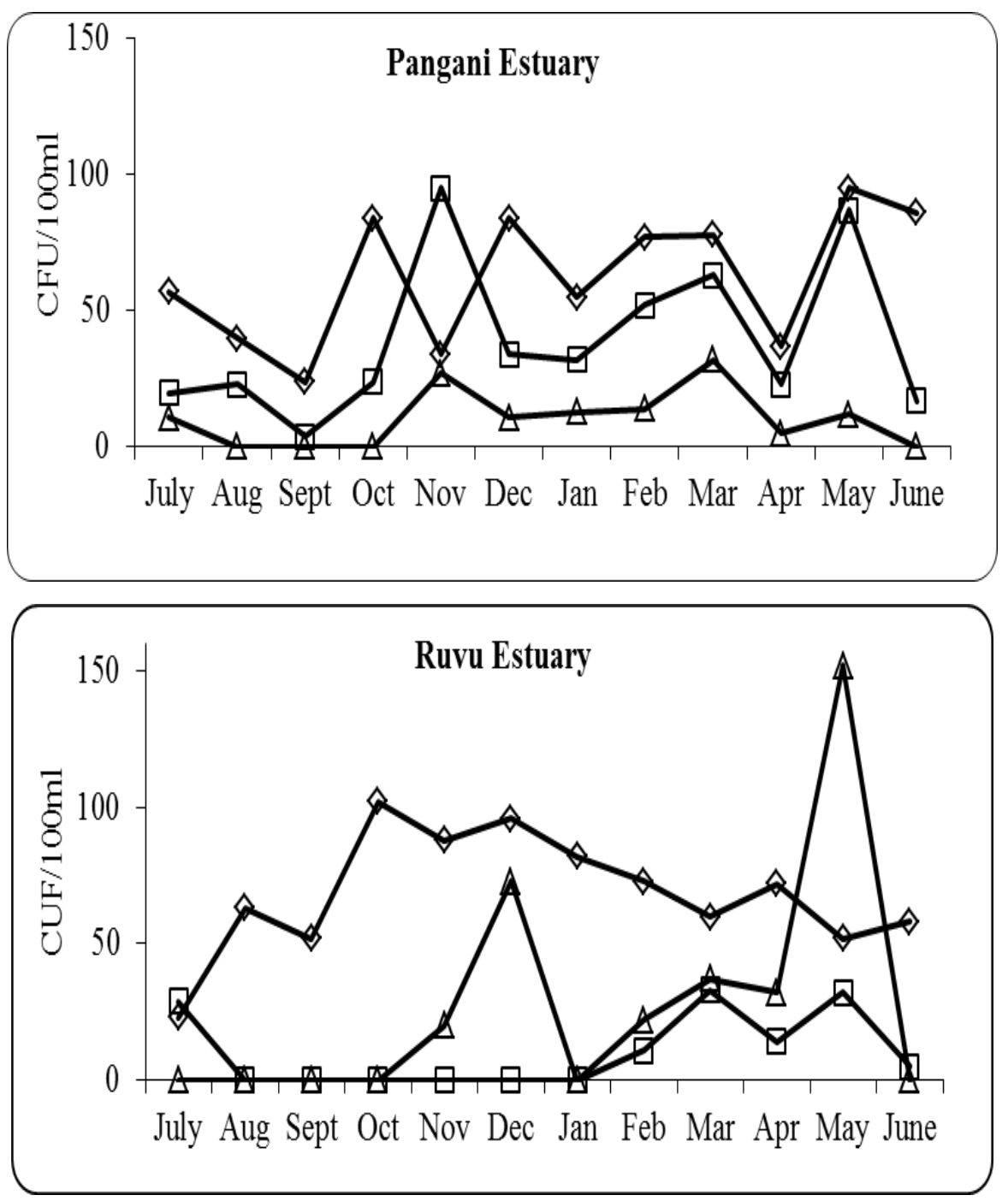


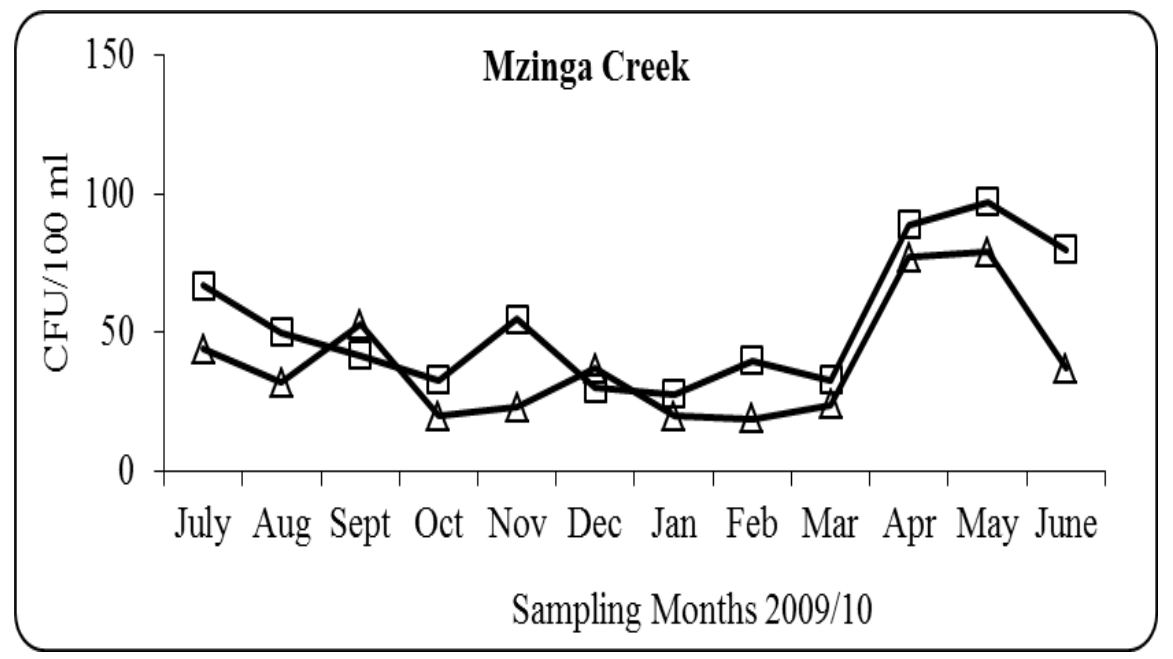

Figure 4. Seasonal variation in ENT counts in the study sites: $(\diamond=$ Station 1 ; Station $2=\square$ and Station $3=\Delta$ )

\subsection{Environmental Parameters}

\subsubsection{Rainfall in the Study Sites}

Monthly rainfall variations in Tanga, Pwani and Dar Es Salaam Regions are shown in Figure 5. The maximum rainfall of $362.2 \mathrm{~mm}$ was recorded in Dar Es Salaam Region in April, while the minimum rainfall value of $1 \mathrm{~mm}$ was recorded in Pwani Region in August 2009. In all the regions the rainfall data showed similar pattern with an average of $112.3 \pm 93,86.5 \pm 94.1$ and $74.7 \pm 104.7 \mathrm{~mm}$ for the regions of Tanga, Pwani and Dar Es Salaam, respectively. The rainfall values recorded during this study did not differ significantly among the sites $(\mathrm{F}=0.5 ; \mathrm{P}=0.6)$.

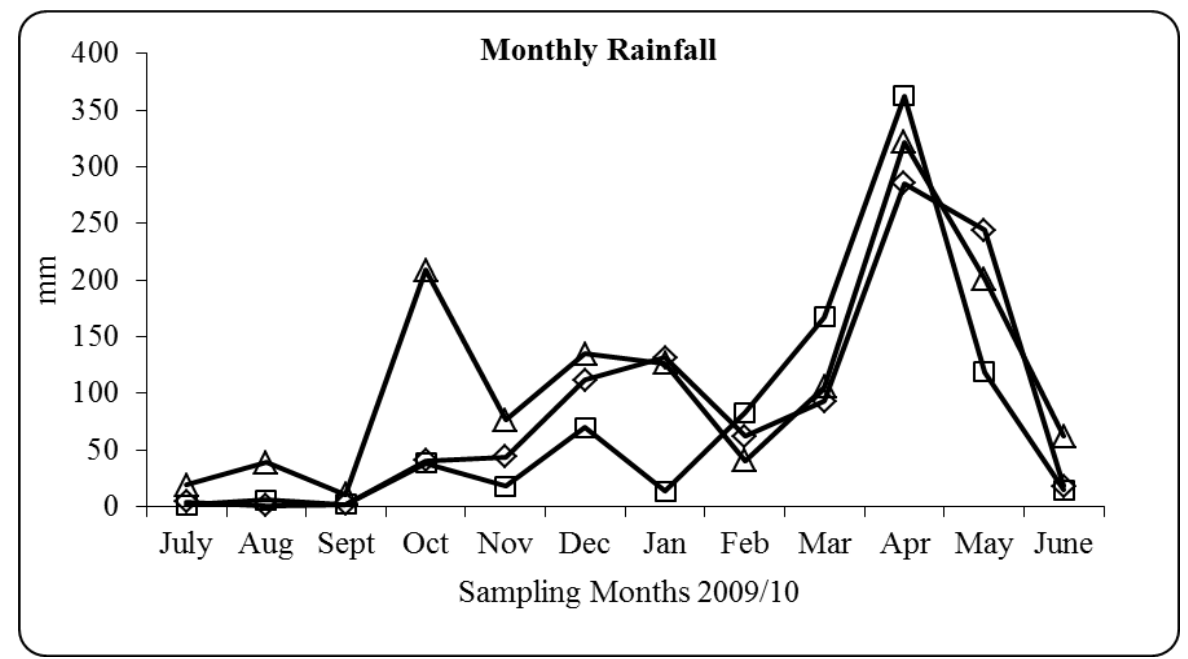

Figure 5. Seasonal variations in the amount of rainfall $(\mathrm{mm})$ in Tanga $(\Delta)$, Pwani $(\diamond)$ and Dar es Salaam ( $\square$ ) Region

\subsubsection{PH in the Study Sites}

The $\mathrm{pH}$ values in the study sites showed similar pattern (Figure 6) ranging from 6.9 to 8.7 with an average of $8.03 \pm 0.3,7.8 \pm 0.5$ and $7.9 \pm 0.4$ for Tanga, Pwani and Dar es Salaam, 


\section{Macrothink}

respectively. However, there was no significant difference in $\mathrm{pH}$ values among these sites (KW $=2.8 ; \mathrm{P}>0.05)$. In general higher $\mathrm{pH}$ values were observed at marine water than in the Brackish and freshwater stations. However, a significant difference was observed in Ruvu estuary ( $\mathrm{F}=10.9 ; \mathrm{P}<0.001)$ but not in Pangani Estuary and Mzinga creek.

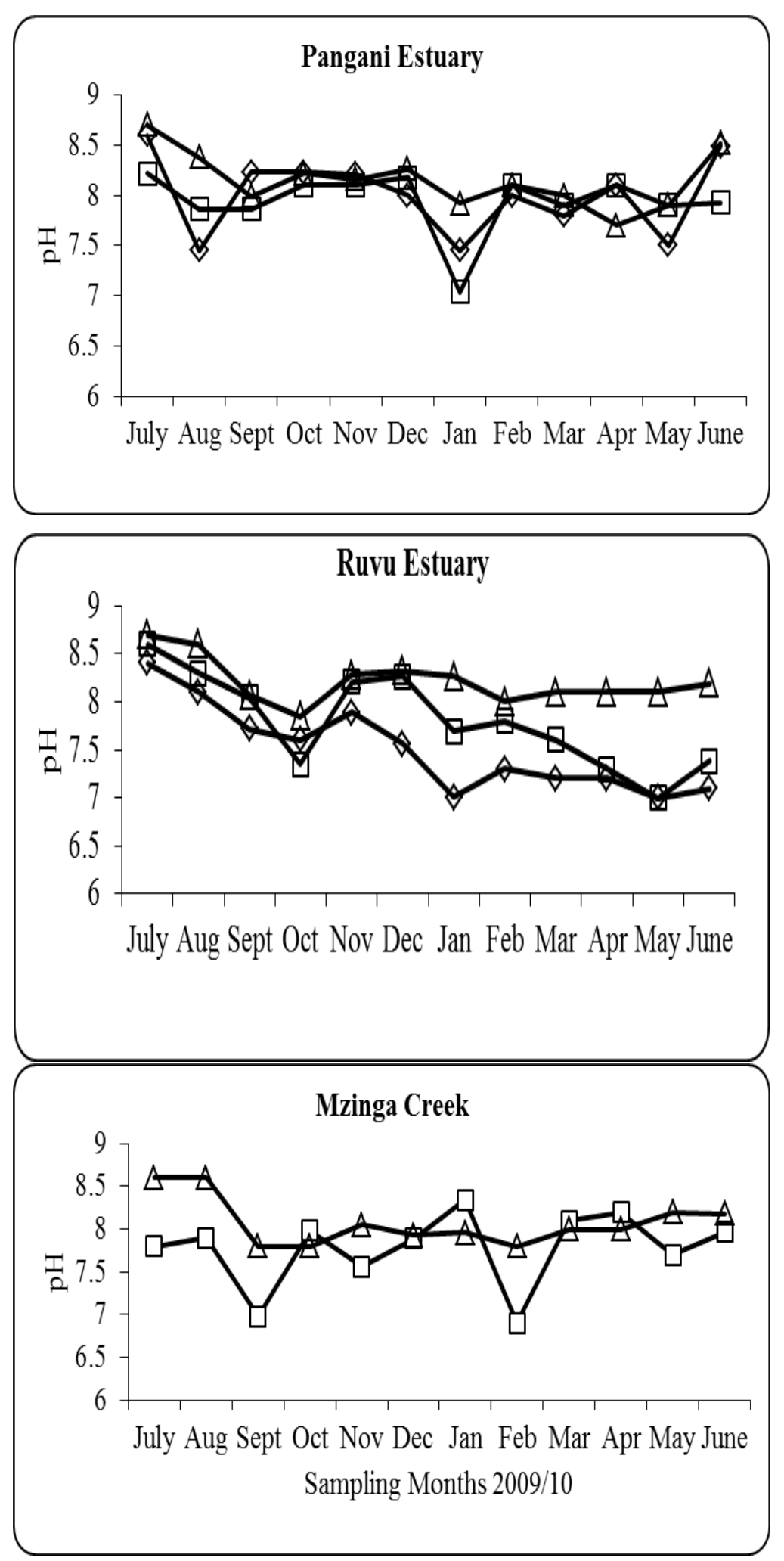




\section{Macrothink}

Figure 6. Seasonal variations in $\mathrm{pH}$ values in the study sites $(\diamond=$ Station $1, \square=$ Station 2 and

$$
\text { Station } 3=\Delta \text { ) }
$$

\subsubsection{Salinity in the Study Sites}

Salinity values consistently increased from freshwater to marine water stations ranging from 0\%o in freshwater station at Pangani and Ruvu Estuaries to 35\% in all marine water stations (Figure 7). There was significant difference in salinity values among sites (KW = 18.7; $\mathrm{P}=$ 0.0001). The higher values were recorded at Dar es Salaam and the Dunn's Multiple test showed a significant difference between Tanga and Dar es Salaam as well as Pwani and Dar Es Salaam $(\mathrm{P}<0.0001)$, but not between Pangani and Ruvu $(\mathrm{P}>0.05)$.

In Pangani salinity values at various stations varied between samplings giving a mean value of $4.6 \pm 5.0,14.6 \pm 8.4$ and $30.83 \pm 4.4 \%$ in freshwater, brackish and marine water stations, respectively. Salinity differed significantly among stations $(\mathrm{KW}=26.2 ; \mathrm{P} 0.001)$ with Dunn's Multiple test showing a significant higher values in marine water compared to freshwater and brackish water stations $(\mathrm{P}=0.001)$ but there were no significant difference between freshwater and brackish water stations $(\mathrm{P}>0.05)$

In Ruvu, the recorded salinity values averaged $1.58 \pm 2.73,13.2 \pm 9.75$ and $29.9 \pm 2.66 \%$ in freshwater, brackish and marine water stations, respectively. Thus, the values were significantly different among stations $(\mathrm{KW}=26.5 ; \mathrm{P}=0.001)$ with Dunn's Multiple test showing the significant difference to be between marine water and freshwater as well and brackish water $(\mathrm{P}=0.001)$ but not between freshwater and brackish water stations $(\mathrm{P}>0.05)$. In Mzinga Creek, salinity values averaged $26.8 \pm 4.2$ and $33.8 \pm 2.3$ in brackish and marine water stations, respectively. The values were significantly higher in marine water than brackish waters ( $U=134 ; \mathrm{P}<0.0002)$.

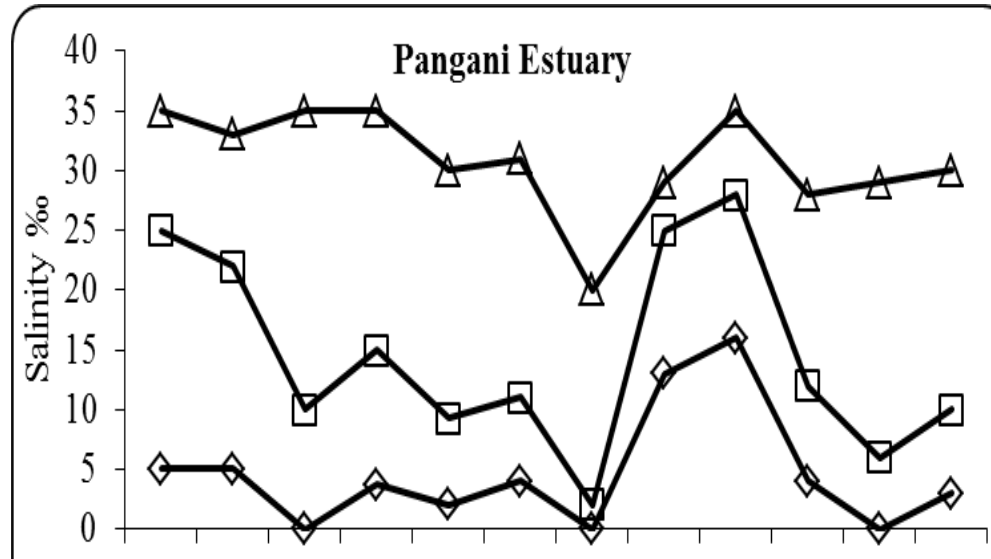

July Aug Sept Oct Nov Dec Jan Feb Mar Apr May June 

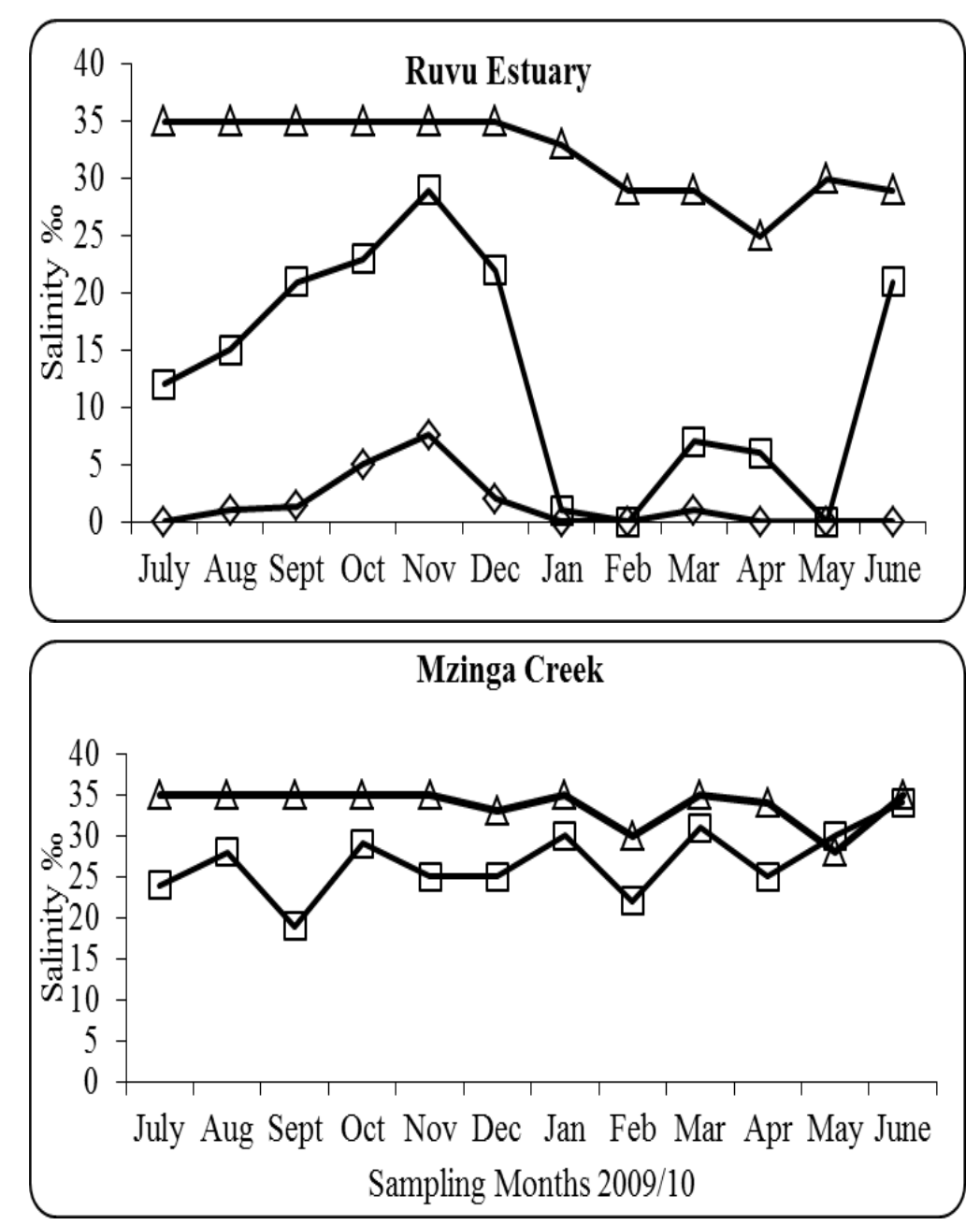

Figure 7. Seasonal variations in salinity in study sites (station $1=\diamond$, station $2=\square$ and station

$$
3=\Delta) \text {. }
$$

\subsubsection{Temperature in the Study Sites}

Water temperature values (Figure 8) ranged from $24.7^{\circ} \mathrm{C}$ to $34.8^{\circ} \mathrm{C}$ and were not significantly different among sites. In Pangani Estuary, temperature values averaged 29.2 $\pm 1.9,29.4 \pm 2$ and $28.9 \pm 1.8^{\circ} \mathrm{C}$ while in Ruvu Estuary values averaged $28.5 \pm 2.21,28.6 \pm 1.95$ and $29.1 \pm 2.1^{\circ} \mathrm{C}$ in fresh, brackish and marine water stations, respectively. In Mzinga Creek, temperature values averaged $29.9 \pm 3.2$ and $29 \pm 2.2^{\circ} \mathrm{C}$ in brackish and marine water stations, respectively. In all cases, there were no significant differences between stations $(\mathrm{P}>0.05)$. 

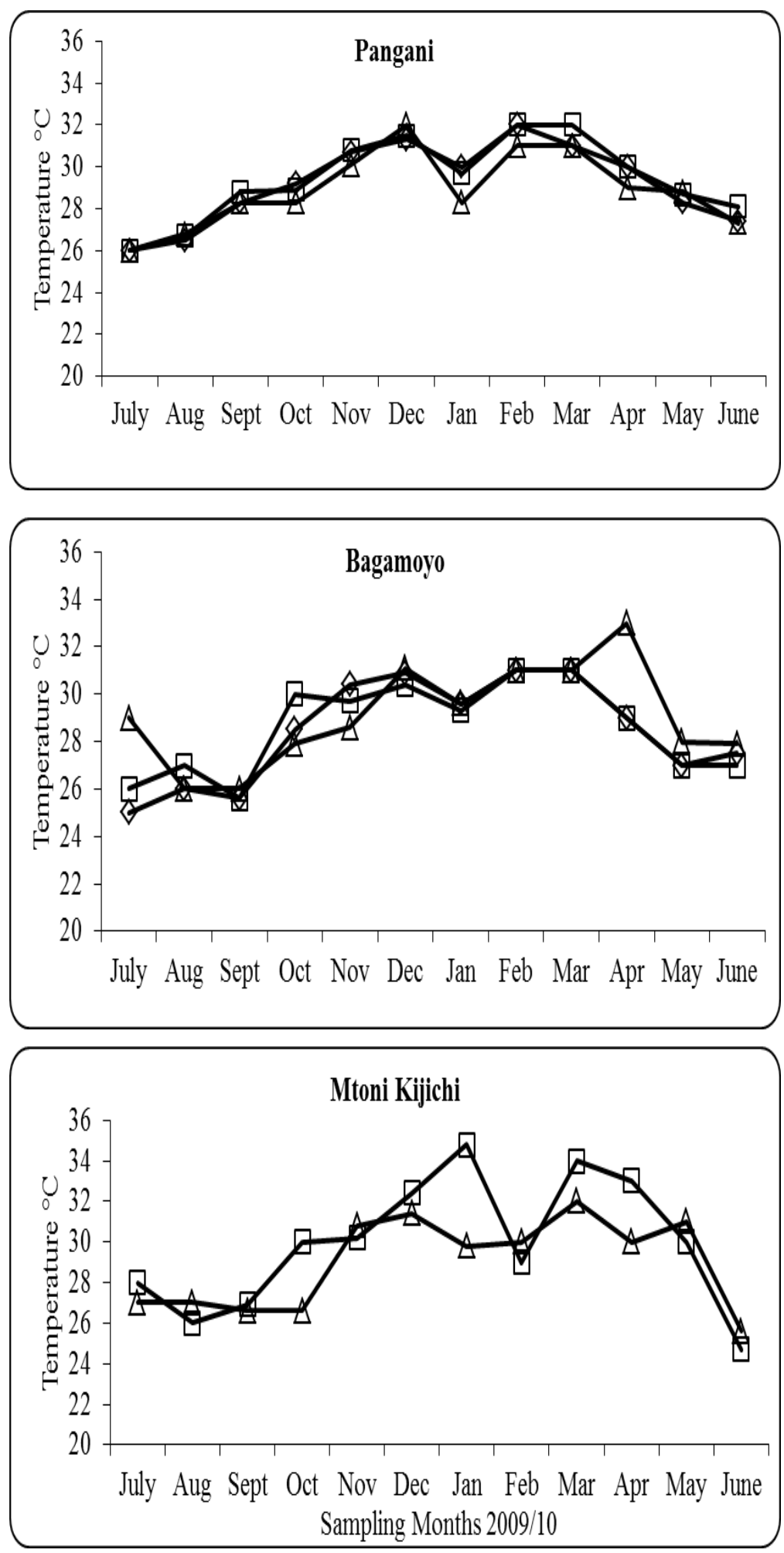

Figure 8. Seasonal variations in water temperature in the study sites (Station $1=\diamond$, Station $2=$

$$
\square \text { Station } 3=\Delta \text { ) }
$$

\subsubsection{Correlation of Faecal Indicator Bacteria with Environmental Parameters}

The results of correlation between the numbers of faecal indicator bacteria and the environmental parameters $(\mathrm{pH}$, Salinity and Temperature) for data from all sites, pooled 
together are shown in Table 1. As expected the faecal indicator bacteria were positively and significantly correlated to each other. In addition, FC and ENT showed negative and significant correlation with salinity $(\mathrm{P}=0.0001$ and 0.0003 respectively). A significant negative correlation was also obtained between ENT and $\mathrm{pH}(\mathrm{P}=0.01)$. On contrast, the FC and ENT were positively correlated with Temperature $(\mathrm{P}=0.036$ and $\mathrm{P}=0.05$ respectively $)$ as shown in Table 1.

Table 1. Correlation matrix of faecal bacteria with environmental parameters using data pooled together from all sites and stations

\begin{tabular}{|lllllll|}
\hline Parameter & TC & FC & ENT & Ph & Sal & Temp \\
\hline FC & 0.847 & & & & & \\
& $\mathrm{P}<0.0001^{*}$ & & & & & \\
\hline ENT & 0.481 & 0.488 & & & & \\
& $\mathrm{P}=0.0002^{*}$ & $\mathrm{P}<0.0001^{*}$ & & & & \\
\hline pH & -0.038 & 0.454 & -0.264 & & & \\
& $\mathrm{P}=0.84$ & $\mathrm{P}=0.98$ & $\mathrm{P}=0.01^{*}$ & & & \\
\hline Sal & -0.485 & -0.516 & -0.362 & 0.426 & & \\
& $\mathrm{P}=0.20$ & $\mathrm{P}<0.0001^{*}$ & $\mathrm{P}=0.0003^{*}$ & $\mathrm{P}<0.0001^{*}$ & & \\
\hline Temp & 0.147 & 0.214 & 0.201 & 0.612 & 0.002 & \\
& $\mathrm{P}=0.39$ & $\mathrm{P}=0.036^{*}$ & $\mathrm{P}=0.05^{*}$ & $\mathrm{P}=0.55$ & $\mathrm{P}=0.98$ & \\
\hline Rainfall & 0.143 & 0.124 & 0.227 & -0.192 & -0.215 & 0.514 \\
& $\mathrm{P}=0.34$ & $\mathrm{P}=0.30$ & $\mathrm{P}=0.63$ & $\mathrm{P}=0.06$ & $\mathrm{P}=0.04 *$ & $\mathrm{P}=0.45$ \\
& & & & & &
\end{tabular}

Key: Bolded values are $\mathrm{r}$ and $*$ shows significant correlation.

\section{Discussion}

The recorded number of Faecal indicator bacteria were in correspondence with other studies performed in the coastal habitats of Tanzania e.g. Abbu and Lyimo (2007) and (Lyimo 2009). In general, the maximum number of faecal indicator bacteria obtained from Mzinga creek was lower than those obtained by Abbu and Lyimo (2007) at this site. This may be due to different ways of sampling where by Abbu and Lyimo (2007) obtained their samples from tidal pools during low tide while inthis study water samples were obtained during high tide in the middle of the creek. Therefore, the lower numbers obtained during our sampling may be as a result of dilution effect (see also Lyimo 2009). Generally the numbers of Total Coliform (TC) were higher than Faecal Coliform (FC) and Enterococcus (ENT) as expected due to the fact that FC is a subset of TC (Prescott et al. 1996) while ENT is normally less in number from feces of human and other warm-blooded animals.

In general, freshwater stations showed higher numbers of faecal indicator bacteria than those obtained in brackish and marine waters which could be due to the proximity of these stations to inhabited areas and other human activities like farming. Since the major cause of bacterial contamination in coastal waters is urban runoff, it is also possible that dilution toward the marine water stations also contributed to the observed low numbers of faecal indicator bacteria in the marine environment. Thus, lack of sewage treatment in inhabited areas results in storm water drains or seepage running in adjacent near shore areas and leading to increased faecal bacterial contamination. This is due to the fact that, many people living in slums and 
rural areas have little or no access to basic necessities, such as clean water, toilet facilities, and sewage disposal (Mohammed, 2002). Although humans or sewage effluents can be sources of faecal indicator bacteria in water, wildlife and waterfowl may also contribute to the observed faecal bacteria contamination (Choi et al., 2003).

The results show that Mzinga Creek is more contaminated with faecal indicator bacteria compared to the other two study sites. This was due to the fact that Mzinga Creek is located in a more populated urban area thereby more exposed to direct sewage disposal and incoming industrial effluents as also reported by Abbu and Lyimo (2007). Several recreation activities including swimming along the creek were also observed, which could also result into further contamination. The use of on-site latrines (Lin and Dushoff, 2001) and other human activities such as direct bathing (Dwight et al., 002) is known to contribute to the high amounts of faecal indicator bacteria loads in the near shore waters. Another possible source of contamination at Mzinga Creek is the direct defecation in the mangrove forest in this site as also reported by Abbu and Lyimo (2007).

The significant positive correlation between the various faecal bacterial indicators is an expected phenomenon as both these organisms originate from similar source and are similarly affected by environmental factors. The significant negative correlation between $\mathrm{pH}$ and ENT as well as between salinity and ENT and between salinity and FC is possibly due to the fact that the marine environment which has high $\mathrm{pH}$ and salinity values compared to freshwater does not favour long survival of the faecal indicator bacteria. The osmotic stress due to high salinity in marine water is known to affect more FC and TC but less on ENT (Paul et al., 1995; WHO 1999). The significant positive correlation between water temperature and FC as well as ENT suggests that high temperature was more conducive for survival of faecal indicator bacteria.

Based on many standards, recreational water is classified as poor when TC is higher than 1000 $\mathrm{CFU} / 100 \mathrm{mls}$ and FC as well as ENT number are higher than $200 \mathrm{CFU} / 100 \mathrm{ml}$ (WHO 1999). However, the presence of TC and FC in the environment may not necessarily indicate presence of human contamination in the water as these indicator bacteria may be naturally present in tropical aquatic environments in the absence of any source of faecal contamination (Paul et al., 1995; Jiang et al., 2007). For this reason ENT may be better indicators of human faecal contamination (USEPA, 1986, 1999; Paul et al., 1995, WHO, 1999) although some literature has also showed that it can as well grow in tropical soils. Nevertheless, many directives recommend ENT as a better predictor of the risk to contract gastrointestinal illness, caused mainly by enteric viruses in sewage contaminated waters (USEPA, 1986). In addition, ENT are not affected by salinity levels and have no growth phase in seawater (Paul et al., 1995). Using these ENT as more reliable standards, our results shows that the waters can be classified as good (11-50 CFU/100 ml) or fair (51-200 CFU/ $100 \mathrm{ml})$. The marine water station at Pangani and Ruvu could be considered as excellent $(<11 \mathrm{CFU} / 100 \mathrm{ml}$ ) for recreational activities while the marine water at Mzinga creek was fair. The brackish water could be classified as good while fresh water was fair.

USEPA (1986) recommends that faecal coliform bacteria in portable water should be less than 
$10 \mathrm{CFU} / 100 \mathrm{ml}$. According to APHA (2005), a level of $200 \mathrm{CFU} / 100 \mathrm{ml}$ indicates needs for follow up testing and investigation while levels exceeding $400 \mathrm{CFU} / 100 \mathrm{ml}$ required posting of warning. In this study some sites showed values, which call for further monitoring. For example, at Ruvu Estuary and Mzinga Creek the number of FC exceeded $200 \mathrm{CFU} / 100 \mathrm{ml}$ in April 2010 and December 2009, respectively. The high numbers could be due to improper disposal of wastewater, density of population and through sewer systems and poorly sited septic tanks. These results implicates on the probability of people around these areas being prone to water-borne infections such as diarrhea or cholera (Esrey et al., 1985; WHO, (2003).

\section{Conclusion and Recommendation}

In general the numbers of faecal indicator bacteria were low and do not pose major risks for swimmers. However, the numbers were high if the water is intended for drinking and shellfish harvesting. Routine measurements of faecal indicator bacteria density in coastal waters of Tanzania is hereby recommended so as to ensure protection of public health.

\section{Acknowledgement}

This work was supported by Marine Sciences for Management Program (MASMA) of the Western Indian Ocean Marine Sciences Association (WIOMSA) through project number MASMA/OR/01. The authors are also grateful to the technical staffs of the department of Molecular Biology and Biotechnology and Department of aquatic science for their technical support and for providing necessary facilities in sampling and identification.

\section{References}

Abbu, A. A., \& Lyimo, T. J. (2007). Assessment of Faecal Bacteria contamination in sewage and non-sewage impacted mangroves ecosystem along the coast of Dar Es Salaam. Tanzania Journal of Science, 33, 27-40.

Ackman, D. S., Mark, S., Mack, P., Caldwell, M., Root, T., \& Birkhead, G. (1997). Swimming associated hemorrhagic colitis due to Escherichia coli 0159:H7 infection: evidence of prolonged contamination of a fresh water lake. Epidemiology and Infections, 199, 1-8. http://dx.doi.org/10.1017/S095026889700770X

APHA. (2005). Standard Methods for the Examination of Water and Wastewater, $18^{\text {th }}$ Ed., American Public Health Association (APHA), American Water Works Association (AWWA) and Water Pollution Control Federation (WPCF), Washington, D.C.

Ashbolt, N. J. (2004). Microbial contamination of drinking water and disease outcomes in developing regions. Toxicolog, 198, 229-238. http://dx.doi.org/10.1016/j.tox.2004.01.030

Byamukama, D., Kansiime, F., Mach, R. L., \& Farnleitner, A. H. (2000). Determination of Escherichia coli contamination with chromocult coliform agar showed a high level of discrimination efficiency for differing faecal pollution levels in tropical waters of Kampala. Uganda Applied Environmental Microbiology, 66, 864-868. http://dx.doi.org/10.1128/AEM.66.2.864-868.2000 


\section{$\triangle$ Macrothink}

Journal of Biology and Life Science ISSN 2157-6076 2013, Vol. 4, No. 2

Canal of the Irrigation System in the Southwestern of Puerto Rico University of Puerto Rico-Medical Sciences Campus. XXVIII Congreso Interamericano de Ingeniería Sanitaria y Ambiental Cancún, México, 27 al 31 de octubre, 2002.

Choi, S., Brown, W. C. J., Becker, S. J., Harwood, V. J., \& Jiang, S. C. (2003). Application of enterococci antibiotic resistance patterns for contamination source identification at Huntington Beach, California. Marine Pollution Bulletin, 46, 748-755. http://dx.doi.org/10.1016/S0025-326X(03)00046-8

Dwight, R., Semenza, J, Barker, D., \& Olson, B. (2002). Association of urban runoff with coastal water quality in Orange Country, California. Water Environ Res, 74, 82-90. http://dx.doi.org/10.2175/106143002X139776

Effler, P., Isaacson, M., Arntzen, L., Heenan, R., Canter, P., Barrett, T., Lee, L., Mamba, C., Levine, W., Zaidi, A., \& Griffin, P. M. (2001). Factors contributing to the emergence of Escherichia coli O157: H7 in Africa. Emerging Infectious Diseases, 7, 812 - 819.

Esrey, S. A., Feachem, R. G., \& Hughes, J. M. (1985). Interventions for the control of diarrheal diseases among young children: improving water supplies and excreta disposal facilities. Bulletin of the World Health Organization, 63(4), 757-772.

Grabow, W. O. K. (1996). Waterborne diseases: Update on water quality assessment and control. Water SA,22, 193-202.

Griesel, M., \& Jagals, P. (2002). Faecal indicator organisms in the Renoster Spruit system of the Modder-Riet River catchment and implications for human users of the water. Water SA, 28, 227-234. http://dx.doi.org/10.4314/wsa.v28i2.4889

Hernández, N. (2002). Evaluation of coliphages and faecal coliforms densities on the Principal Water pollution a threat to humanity. Accessed on $2^{\text {nd }}$ February 2012. http://www.infoforhealth.org

Hysko, M., Gace, B. \& Puto, K. (2010), "Microbial Water Pollution of Vjosa River and the Vegetable Contamination by Irrigation. BALWOS 2010-Ohlid, Republic of Macedonia, 20, 25 .

Jiang, S. C., Chu, W., Oslon, B. H., He, J., Choi, S., Zhang, J., Le, J. Y., \& Gedalanga, P. B. (2007). Microbial source tracking in a small southern California urban watershed indicates wild animals and growth as source of fecal bacteria. Applied Microbiology and Biotechnology, 76, 927-934. http://dx.doi.org/10.1007/s00253-007-1047-0

LeChevallier, M. W., \& Buckley M. (2007). Clean Water: What is Acceptable Microbial Risk. American Society for Microbiology, Washington D.C. pp7.

Lin, B., \& Dushoff, J. (2001). Mangrove filtration of anthropogenic nutrients in the Rio Coco Solo. Rio Coco Solo, Panama. 12 pp.

Lyimo, C. W., Shayo, R., \& Lyimo, T. J. (2007). Community Awareness on Microbial water pollution and Its Effects on Health Development in Urban Tanzania: A Case Study of Tabata 
and Kiwalani Wards in Ilala District in Dar Es Salaam Region. Tanzania Journal of Development Studies, 7, 103-114.

Lyimo, T. J. (2009). Microbial and nutrient pollution in the coastal bathing waters of Dar es Salaam, 19, 527-537.

Mmochi, A. J., \& Francis, J. (1999). Long term monitoring of water quality in Zanzibar, Tanzania. The Institute of Marine Sciences, Zanzibar. Pp. 31.

Mohammed, S. M. (2002a). Pollution management in Zanzibar: the need for a new Approach. Ocean \& Coastal Management, 301-311. http://dx.doi.org/10.1016/S0964-5691(02)00060-1

Mohammed. S. M. (2002b). A review of water quality and pollution studies in Tanzania. Ambio, 31, 617-620.

Olsen, S. J., Miller, G., Breuer, T., Kennedy, M., Higgins, C., Walford, J., McGee, G., Fox, K., Bibb, W. \& Mead, P. (2002). A waterborne outbreak of Escherichia coli 0157:H7 infections and haemolytic uremic syndrome: implications for rural water systems. Emerging Infectious Diseases, 8, 370-375. http://dx.doi.org/10.3201/eid0804.000218

Paul, J. H., Rose, J. B., Jiang, S., Kellog, C., \& Shinn, E. A. (1995). Occurrence of faecal indicator bacteria in surface waters and subsurface aquifer in Key Largo. Applied and Environmental Microbiology, 61, 2235-2241.

Penrose, K., Caldas de Castor, M., Werema, J., \& Ryan, E. T. (2010). Informal Urban Settlements and Cholera Risk in Dar es Salaam, Tanzania. www.plosntds.org. Viewed on July, 2010.

Prescott, L., Harley, J. \& Klein, D. (1996). Microbiology, $3^{\text {rd }}$ edn. WCB Publishers: Chicago.

Rubindamayugi, M. S. T. (1996). Faecal bacteria contamination of coastal and River Msimbazi waters in Dar Es Salaam. In: Kivaisi A, Muruke M \& Rubindamayugi M (eds.) Economic development and Environment in Sub- Saharan Africa. Dar es Salaam University Press, 209-217.

Thompson, T. \& Khan, S. (2003). Situation analysis and epidemiology of infectious disease transmission: a South-Asian regional perspective. International Journal of Environmental Health Research, 13, S29-S39. http://dx.doi.org/10.1080/0960312031000102787

USEPA. (1986). Bacteriological ambient water quality criteria for marine and fresh recreational waters. EPA 440/5-84-002.U.S. Environmental Protection Agency, Office of Research and Development, Cincinnati, $\mathrm{OH}$.

USEPA. (1999). Action Plan for Beaches and Recreational Water. EPA/600/R-98/079, Washington, DC.

Van Bruggen, J. J. (1990). A preliminary study on environmental pollution on Zanzibar. Zanzibar Environmental Study Series No. 6. 


\section{Macrothink}

Vega, M., Pardo, R, Barrado, E. \& Deban, L. (1998). Assessment of seasonal and polluting effects on the quality of river water by exploratory data analysis. Water Research, 32, 3581-3592. http://dx.doi.org/10.1016/S0043-1354(98)00138-9

WHO (1999). Health-based monitoring ofrecreational waters: the feasibility of a new approach (the "Annapolis Protocol”), WHO/SDE/WSH/99.1. Geneva: World Health Organization, p. 50 .

WHO (2003). Guidelines for safe recreational water environment, volume 1: coastal and fresh waters. Geneva, Switzerland. Pp 253. Criteria and other supporting information, Geneva, Switzerland World Health Organization.

WHO and UNICEF. (2004). Meeting the MDG Drinking Water and Sanitation: A Mid Term Assessment of Progress. Geneva: WHO/UNICEF. ISBN 9241562781

Zar, J. (1999) Biostastical Analysis. $3^{\text {rd }}$ ed. USA, Prentice Hall International Edition. pp 180-220.

\section{Copyright Disclaimer}

Copyright reserved by the author(s).

This article is an open-access article distributed under the terms and conditions of the Creative Commons Attribution license (http://creativecommons.org/licenses/by/3.0/). 